\title{
Critical Discourse Analysis Sara Mils in The Online News Text About The Sinking of Ships at Indonesian Waters
}

\author{
Syarifa Rafiqa ${ }^{*}$, \\ Universitas Borneo Tarakan \\ *) Jl. Amal Lama, No. 1. Kota Tarakan, 771112, Indonesia; \\ e-mail: vicka.cutegirl@gmail.com
}

\begin{abstract}
This study examines how the women in this case Minister Susi are presented in the news text about the sinking of ships in Indonesian waters. Research was conducted on the 5 most popular online news sites in Indonesia. The analysis used is the critical discourse analysis of Sara's perspective, by analyzing 3 elements, namely the position of the subject-object, the position of the reader, and the position of the media. The results of this study indicate that, the position of the subject is the writer of the news and the object is Susi, because women in online news texts define their position and they can also present themselves and reinforced the author by displaying the ideas of the object. The position of the reader is the insertion of cultural codes, the reader will approve the ideas of the author on the orientation of values so that readers will place himself in the main character in the text. Media position on online news sites that provide positive images, namely detik.com, kompas.com and okezone.com. While those who reported neutrally were tribunnews.com and republika.co.id.
\end{abstract}

Keywords: Critical Discourse Analysis, Mills, Susi, Online News.

Article History: Received: 25/05/2019; Revised: 22/06/2019; Accepted: 02/07/2019; Published: 31/07/2019. How to Cite (MLA $7^{\text {th }}$ : Rafiqa, Syarifa. "Critical Discourse Analysis Sara Mils in the Online News Text About the Sinking of Ships at Indonesian Waters." Hortatori Jurnal Pendidikan Bahasa dan Sastra Indonesia 3.01 (2019): 37-43. Print/Online. Copyrights Holder: Syarifa Rafiqa. First Publication: Hortatori Jurnal Pendidikan Bahasa dan Sastra Indonesia (2019). c) (7) (2)

This work is licensed under a Creative Commons Attribution-ShareAlike 4.0 International License.

\section{Pendahuluan}

Teknologi digitalisasi membuat informasi dapat diakses siapapun dan dimanapun, situs-situs berita di dalam ruang cyber disebut media online, yang merupakan media berbasis telekomunikasi dan multimedia (komputer dan internet), yang termasuk kategori media online salah satunya yaitu portal berita (Romli). Isi dari sebuah pemberitaan pada media adalah konstruksi realitas dengan bahasa sebagai perangkat atau alat dasarnya. Dalam proses konstruksi realitas, bahasa adalah unsur utama dan merupakan instrumen pokok dalam menceritakan realitas, karena melalui bahasa yang tepat seseorang dapat diatur pola pikirnya oleh media. Perilaku kebahasaan mengekspresikan makna sosial yang kompleks, melalui bahasa kita dapat menegaskan atau menyerahkan kontrol dengan menunjukan berbagai kelompok sosial yang diidentifikasikan, peran sosial yang dianut, dan nilai-nilai yang terkadang saling bertentangan yang didukung (Degyan and Huwaill). Dengan demikian mempelajari perempuan dalam teks pada media berarti mempelajari cara-cara makna berfungsi untuk mempertahankan dominasi, dengan kata lain bahasa bukan satu-satunya instrument komunikasi atau bahkan pengetahuan, tetapi juga merupakan instrumen kekuasaan (Fairclough, Critical Discourse Analysis The Critical Study of Langauge; Fairclough, Language and Power). Misalnya, bagaimana seorang perempuan ditampilkan dalam teks, Perempuan selama ini cenderung ditampilkan dalam teks sebagai pihak yang lemah, marjinal dibanding dengan lakilaki (Arikan). Banyaknya berita-berita yang menampilkan perempuan sebagai objek pemberitaan (Sobari and Faridah; Sukaesih and Brida), perempuan diingatkan setiap hari bahwa perilaku menyimpang yang mereka perlihatkan dipantau terus menerus (Fisher), serta mencegah pendekatan feminis pada penindasan perempuan di India (Liddle and Rai). Bahkan hingga saat ini, budaya sampai batas tertentu masih diatur 
oleh sistem patriarki, status perempuan di masyarakat akan selalu berada di posisi kedua (Radzi and Musa; Zulkifli) akibat dominasi laki-laki ini ideologi dan wacana kewanitaan dan maskulinitas sangat mempengaruhi efek gender dalam lingkungan sosial (Litosseliti and Leadbeater). Gender dan praktik representasi media massa telah lama menjadi perhatian tidak hanya bagi para peneliti media (Gauntlett; Gill) tetapi juga sejumlah ahli bahasa yang terkait dengan penelitian bahasa dan gender (Litosseliti and Leadbeater; McPhillips and Speer), yang melhat media sebgai situs utama untuk membangun diskursif identitas gender dan pemeliharaan ideologi gender dominan. Penelitian ini mengkaji secara khusus bagaimana hubungan antara bahasa dan gender dikonstruksi dalam teks-teks media, dan ini bertujuan untuk menginterogasi sejumlah kecil artikel yang diambil dari edisi online surat kabar nasional di Indonesia yang paling banyak dibaca mengenai pemberitaan media online menteri perempuan Susi Pudjiastuti pada kebijakannya pada penenggelaman kapal di perairan Indonesia. Studi ini memberikan konstribusi terhadap pemenuhan tujuan politik untuk memperbaiki ketidakseimbangan gender, (Mills and Mullany) dan ini mengindikasikan bahwa selangkah lebih dekat kearah mewujudkan emansipasi dan kesetaraan gender. Fokus penelitian ini adalah analisis wacana kritis sara Mills pada media online dalam pemberitaan penenggelaman kapal di perairan Indonesia. Bagaimana perempuan dalam hal ini menteri Susi ditampilkan dalam teks. Karena perempuan cenderung ditampilkan dalam teks sebagai pihak lemah, marjinal dibanding pihak laki-laki. Bahkan, pada praktiknya, laki-laki diasosiasikan dengan, rasionalitas, objektivitas, sains, dank eras sedangkan perempuan diasosiasikan dengan, emosional, subjektivitas, alami, lembut, seni dan hal ini diperdebatkan dalam ilmu sosial hingga saat ini (Litosseliti and Leadbeater). Ketidakadilan dan penggambaran yang buruk mengenai perempuan menjadi sasaran utama penelitian ini. Didalam media berita online adanya dominasi pihak-pihak tertentu didalamnya akan sangat mempengaruhi wacana apa yang akan ditunjukan. Dikarenakan pihak yang mampu mendominasi suatu hal, dapat dengan mudah menunjukan suatu makna pada pihak ataupun orang yang tidak mempunyai dominasi sama sekali.

1. Analisis Wacana Kritis:Sara Mills

Sebetulnya, banyak model analisis wacana yang diperkenalkan dan dikembangkan oleh para ahli yang menyajikan model-model analisis wacana yang dikembangkan oleh (Fairclough, Critical Discourse Analysis The Critical Study of Language; Dijk; Kress and Leeuwen; Foucault et al.; Mills, Feminist Stylistics). Analisis wacana kritis (AWK) menyediakan teori dan metode yang bisa digunakan untuk melakukan kajian empiris tentang hubungan-hubungan antara wacana dan perkembangan sosial dan kultural dalam domain-domain sosial yang berbeda (Jorgensen and Phillips). (Mills, Language and Sexism) menitik beratkan perhatiannya pada wacana mengenai feminisme ditampilkan pada media, menunjukkan cara kerja media bias dalam menampilkan wanita. Dengan demikian apa yang ditampilkan oleh Mills dikenal dengan persfektif feminis. Mills meyakini bahwa teks maupun gambar secara tidak langsung berkomunikasi dengan khalayak. Oleh karena itu Mills memusatkan perhatian pada gender dan posisi subjek-objek. Secara umum, ada dua hal yang diperhatikan dalam anlisis: pertama, bagaimana aktor dalam teks tersebut diposisikan dalam pemberitaan. Siapa pihak yang diposisikan dalam teks dan apa akibatnya. Kedua, bagaimana subjek-objek diposisikan dalam teks. Teks dimaknai di sini sebagai hasil negoisasi antara subjek dan objek.

Di samping itu, (Mills, Feminist Stylistics) juga menaruh perhatian pada bagaimana pembaca dan penulis (dalam konteks penelitian ini yaitu pembaca dan media) ditampilkan dalam teks. Posisi Subjek-Objek, analisis atas bagaimana posisi-posisi aktor dalam teks (program) ditampilkan secara luas akan menyingkap bagaimana ideologi dan kepercayaan dominan bekerja dalam teks. Posisi sebagai subjek atau objek dalam representasi mengandung muatan ideologis tertentu. Pertama, posisi ini akan menunjukkan batas tertentu sudut pandang penceritaan. Artinya sebuah peristiwa atau wacana akan dijelaskan dalam sudut pandang subjek sebagai narator dari suatu peristiwa. Dengan demikian, pemaknaan khalayak akan tergantung kepada narator sebagai juru warta kebenaran. Kedua, sebagai subjek representasi narator bukan hanya memiliki keleluasaan dalam menceritakan peristiwa tetapi juga menafsirkan berbagai tindakan yang membangun peristiwa tersebut, dan kemudian hasil penafsirannya mengenai peristiwa itu digunakan untuk membangun pemaknaan dia yang disampaikan kepada khalayak. Ketiga, proses pendefinisian tersebut bersifat subjektif, maka perspektif dan sudut pandang yang dipakai tersebut akan turut berpengaruh terhadap bagiamana sebuah peristiwa dideifinisikan. Dalam wacana feminis, posisi (subjek-objek) dalam wacana akan turut menempatkan posisi perempuan ketika ditampilkan dalam sebuah wacana. 


\section{Posisi Pembaca}

Model yang diperkenalkan oleh (Mills, Feminist Stylistics) mengasumsikan bahwa teks adalah suatu hasil negosiasi antara penulis (media) dan pembaca. Oleh karena itu, Mills berpandangan dalam suatu teks posisi pembaca sangatlah penting dan harus diperhitungkan dalam teks, dalam penelitian ini yaitu bagaimana pembaca diposisikan dalam teks. Bagaimana media melalui teks yang dibuat menempatkan dan memposisikan pembaca dalam subjek tertentu dalam seluruh jalinan teks. Penempatan posisi pembaca ini umumnya berhubungan dengan bagaimana penyapaan/penyebutan dilakukan dalam program yang menurut Mills dilakukan secara tidak langsung (indirect address) melalui dua cara. Pertama, mediasi yaitu penempatan posisi kebenaran pada pihak/karakter tertentu sehingga pendengar akan mensejajarkan dirinya sendiri dengan karakter yang tersaji dalam teks. Kedua, melalui kode budaya atau nilai budaya yang berupa nilai-nilai yang disetujui bersama, yang dipakai pembaca ketika menafsirkan suatu teks.

3. Posisi Media

Media bukanlah sekedar saluran yang bebas, ia juga subjek yang mengkonstruksikan realitas, lengkap dengan pandangan, bias dan keberpihakannya. Seperti yang dikatakan oleh Tonny Bennett, media dipandang sebagai agen kontruksi sosial yang mendefinisikan realitas sesuai dengan kepentingannya (Eriyanto, 2001:36). Disini, media bukan sarana yang netral melainkan memiliki keberpihakan terhadap suatu hal tetentu. Di dalam media, ideologi yang dianut akan menentukan apa yang baik dan apa yang buruk untuk dimapankan kepada khalayak. Oleh karena itu, ideologi menjadi salah satu faktor yang penting bagi media dalam menentukan arah teksnya (11pt)

\section{Metode}

Metode penelitian yang digunakan adalah metode kualitatif dengan menggunakan pendekatan Analisis Wacana Kritis Sara Mills terhadap 5 situs berita online mengenai menteri perempuan Susi Pudjiastuti dalam pemberitaan penenggelaman kapal di perairan Indonesia pada tanggal 2 April 2017. Bagaimana berita online menampilkan menteri perempuan sebagai objek pemberitaan. Fenomena pemberitaan menteri susi, sejak awal menjadi menteri hingga saat ini menarik perhatian pembaca karena keberaniannya dalam bertindak terutama pada pencurian ikan di wilayah Indonesia hingga saat ini sudah hampir 500 kapal yang telah ditenggelamkan. Adapun situs berita online yang digunakan dalam penelitian ini yaitu 5 situs berita online terpopuler di Indonesia menurut IT-Jurnal.com yaitu, Detik.com, Kompas.com, Tribunnews.com, Republika.co.id dan Okezone.com. teknik pengumpulan data yang digunakan adalah dokumentasi yang berupa berita yang diterbitkan 5 situs popular khususnya yang memuat penenggelaman kapal diperairan Indonesia pada tanggal 1 April 2017.

\section{Hasil dan Diskusi}

Model analisis wacana kritis oleh (Foucault et al.; Mills, Feminist Stylistics; Mills, Language and Sexism) ini memiliki dua konsep dalam analisisnya. Konsep pertama yang ingin dilihat adalah mengenai posisi actor yang ditampilkan dalam teks. Posisi yang dimaksud yaitu posisi subjek dan objek, siapa yang menjadi pencerita (subjek) dan siapa yang diceritakan (objek). Kemudian posisi pembaca, bagaimana posisi pembaca yang ditampilkan dalam teks, bagaimana pembaca memposisikan dirinya dalam teks yang ditampilkan. Kepada kelompok manakah pembaca mengidentifikasikan dirinya serta bagaiman penulis menyampaikan agenda besar yang ingin disampaikan pada pembaca.

1. Posisi Subjek-Objek

Dalam wacana yang ada pada situs berita detik.com dengan judul "2 Kapal Pencuri Ikan Ditenggelamkan di Ambon, ini Penampakannya" pada tanggal 2 April 2017. Penulis disini sebagai subjek (pencerita) yaitu seorang perempuan yang bernama Rina Atriana dan menampilkan menteri Susi sebagai objek yang diceritakan. Menteri susi dinilai sangat tegas dalam menerepakan kebijakan peneggelaman kapal. Susi berharap illegal fishing diperairan indonesia murni proses karena pengadilan dan tidak ada campur tangan invisible hand yang mempengaruhi. Dalam pemberitaan, susi memiliki kesempatan untuk menampilkan dirinya sendiri dan ditampilkan oleh penulis dengan mengutip beberapa gagasan yang dikemukakan oleh Susi yaitu "Supaya nanti masyarakat bisa tahu, ada 
jamannya ribuan kapal asing bebas datang mencuri ikan. Dan mereka pun tahu, Indonesia bisa mengatasi kejahatan tersebut". Situs berita selanjutnya yaitu kompas.com dengan judul berita "Menteri Susi: Tenggelamkan Kapal Sino, Simbol Kemenangan Berantas Pencurian Ikan" pada tanggal 2 April 2017. Subjek nya seorang perempuan bernama Nabilla Tashandra yang menulis dalam beritanya tentang bagaiman Menteri susi menenggelamkan kapal-kapal yang melakukan pencurian ikan di Perairan Indonesia. Dalam pemberitaannya menteri susi ditampilkan sebagai penegakan hukum, hal ini ditandai dengan yang dilakukan susi dalam menenggelamkan kapal bahkan menjadi sejarah di dunia perikanan Indonesia sehingga dapat memotivasi masyarakat untuk memberantas kejahatan tersebut dimasa depan. Sedangkan, pemberitaan ini sedikit berbeda ketika subjek penceritanya adalah seorang laki-laki seperti yang dilakukan oleh situs berita online Tribunnews.com dengan judul "Susi Pimpin langsung Penenggelaman 81 Kapal Pencuri Ikan" pada tanggal 1 April 2017. Subjeknya adalah Fabian Januarius yang dalam pemberitaannya susi menampilkan dirinya sendiri, hal ini ditandai dengan kutipan yang dilakukan penulis seperti perhitungan bahan peledak yang tidak akan menggangu lingkungan hidup kawasan konservasi laut dan agar pelaku jera dan tidak mencuri ikan lagi, seperti "Kami sudah perhitungkan agar ini (peledakan) tidak mengganggu lingkungan hidup, kawasan konservasi laut, dan juga keamanan navigasi laut kita". Penulis hanya mengutip 2 kalimat Menteri Susi dan hanya memberikan infomasi tentang jumlah kapal yang ditenggelamkan serta lokasi penenggelamannya. Pada pemberitaan ini objek sendiri yang menampilkan dirinya dan gagasanya. Senada dengan hal tersebut, situs republika.co.id juga memiliki subjek seorang laki-laki yang bernama Bilal Ramadhan dengan judul berita "Menteri Susi Tenggelamkan 81 Kapal Pencurian Ikan Ilegal" pada tanggal 2 April 2017 yang dalam pemberitaan susi menampilkan dirinya sendiri, hal ini ditandai dengan hanya satu kutipan langsung yang dilakukan penulis, yaitu "saya menghitung mundur dari 10, kemudian silahkan saudara ledakan kapal-kapal itu" selebihnya hanya menjelaskan informasi mengenai penenggelaman kapal. Berbeda halnya dengan situs berita online okezone.com, subjeknya seorang laki-laki yang bernama Giri Hartomo dengan judul berita "Berantas Pencurian ikan, Menteri Susi Kembali Tenggelamkan Kapal di Ambon" pada tanggal 1 April 2017. Dalam pemberitaan, Menteri susi memiliki kesempatan untuk menampilkan dirinya sendiri dan ditampilkan oleh penulis dengan mengutip beberapa gagasan yang dikemukakan oleh Susi. Penulis menampilkan Menteri Susi melakukan penegakan hukum dengan menenggelamkan kapal dan akan menjadi sejarah di dunia perikanan Indonesia.

Dari temuan data di atas dapat kita simpulkan bahwa penulis perempuan dan penulis lakilaki sangat berbeda dalam menuliskan sebuah berita, berita yang tanggal, objek dan topiknya sama namun diulas dengan berbeda. Hal ini dapat dilihat dengan 2 penulis perempuan menampilkan sosok Menteri susi dengan menjelaskan gagasanya sendiri kemudian diperkuat oleh penulis dengan ditampilkan penguatan gagasan dalam teks tersebut. Namun berbeda dengan 2 penulis laki-laki yang membiarkan Menteri susi menampilkan gagasan dirinya sendiri melalui kutipan langsung yang dilakukan penulis, dan selanjutnya penulis hanya menambahkan informasi tentang penenggelaman kapal. Berbeda dengan kedua penulis laki-laki sebelumnya, penulis laki-laki dari situs okezone.com menampilkan sosok Menteri susi dengan menjelaskan gagasanya sendiri melalui kutipan langsung dan kemudian diperkuat dengan ditampilkannya gagasan penulis tersebut. Hal ini mengindikasikan bahwa perempuan memiliki kesadaran untuk mengembangkan perspektif para jurnalis perempuan mengenai isu perempuan (Suhara). Adapun dapat kita lihat perbedaannya dengan sangat jelas pada grafik 1, yaitu grafik yang menjelaskan subjek laki-laki (1) dan perempuan (2), kemudian menomori gagasan dengan (1) menampilkan diri sendiri, (2) ditampilkan penulis, (3) menampilkan diri sendiri dan ditampilkan penulis. 


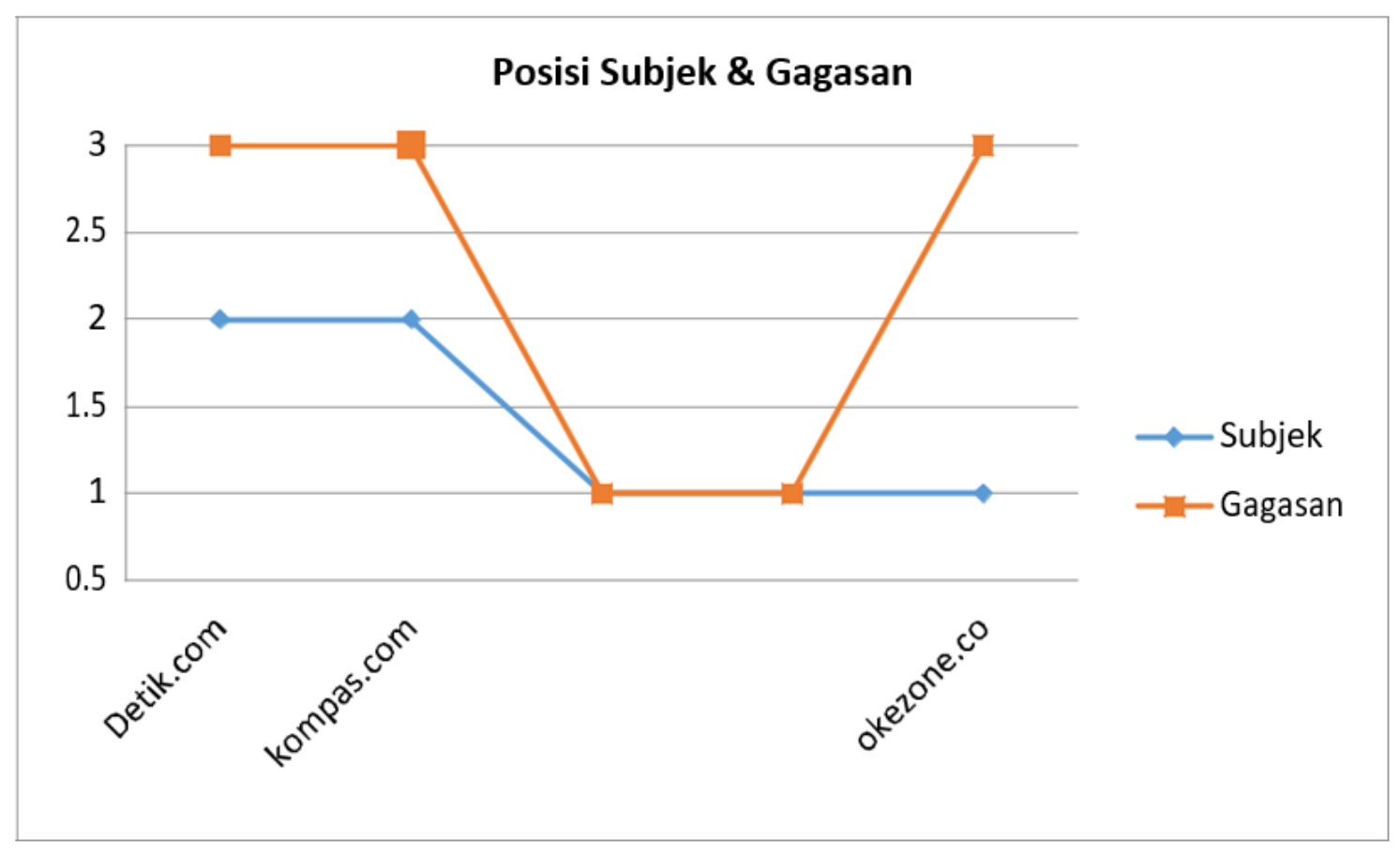

Grafik 1. Posisi Subjek dan Gagasan

\section{Posisi Pembaca}

Berita bukanlah semata sebagai hasil produk dari wartawan, teks dianggap sebagai hasil negoisasi antara penuls dan pembaca. Pembaca ditempatkan bukan hanya sebagai pihak yang menerima teks, tetapi juga pihak yang ikut melakukan transaksi sebagaimana akan terlihat dalam teks, karena berita adalah hasil kesepakatan antara keinginan wartawan dengan pembacanya (Mills, Feminist Stylistics; Sobari and Faridah). Pertama, teks pada situs detik.com, penulis memasukan unsur kode budaya untuk membantu pembaca menempatkan dirinya terutama dengan orientasi nilai yang disetujui dan dianggap benar. Dengan disisipkannya kode budaya seperti para pelaku illegal fishing bisa murni diproses di pengadilan, maka pembaca akan menyetujui gagasan dari penulis terhadap orientasi nilai yang ada pada masyarakat, sehingga pembaca akan menempatkan dirinya pada tokoh utama dalama teks. Kedua, teks pada situs kompas.com, penulis menyisipkan unsur mediasi sebagai alat berneoisasi antara penulis dan pembaca. Kalimat sapaan tersebut, otomatis akan mengarahkan pembaca untuk menyetujui gagasan yang dikemukakan penulis atas peran menteri Susi, sehingga penenggelaman kapal merupakan simbol kedaulatan negara, maka pembaca akan memposisikan dirinya sebagai pihak yang dimenangkan di dalam teks tersebut, dalam hal ini adalah Indonesia. Ketiga, teks pada situs tribunnews.com, penyisipan kode budaya seperti "monumen yang menggambarkan usaha Indonesia dalam memberantas Illegal, Unreported, Unregulated Fishing (IUUF)", kalimat di atas mensugesti sejumlah informasi yang dipercayai dan diakui secara bersama dianggap sebagai kebenaran. Kode budaya merupakan kode yang dapat digunakan oleh pembaca untuk memahami niali terutama yang berkaitan dengan yang mendapat kesepakatan dengan pembacanya. Keempat, teks pada situs republika.co.id, penulis menyisipkan unsur mediasi sebagai alat bernegoisasi antara penulis dan pembaca. Kalimat sapaan "mereka" tersebut, otomatis akan mengarahkan pembaca untuk memposisikan diri sebagai pelaku penangkapan ikan ilegal dengan memberikan informasi tentang hukuman dan undang-undang yang berlaku, sehingga penenggelaman kapal merupakan salah satu konsekuensinya. Kelima, teks pada okezone.com, Dengan disisipkannya kode budaya seperti "penegakan humum yang dilakukan menteri Susi selama ini, menenggelamkan kapal di dunia perikanan indonesia dan dapat dijadikan motivasi bagi seluruh lapisan masyarakat", maka pembaca akan menyetujui gagasan dari penulis terhadap orientasi nilai yang ada pada masyarakat, sehingga pembaca akan menempatkan dirinya sebagai masyarakat yang termotivasi karena penegakan hukum yang telah dilakukan Menteri Susi. 
Posisi pembaca juga merupakan hal yang penting untuk dianalisa. Penempatan posisi pembaca ini berhubungan dengan penyapaan /penyebutan kepada pembaca yang ditampilkan dalam pemberitaan. Hal ini dilakukan secara tidak langsung yaitu melalui 'mediasi dan 'kode budaya' (Mills, Feminist Stylistics).

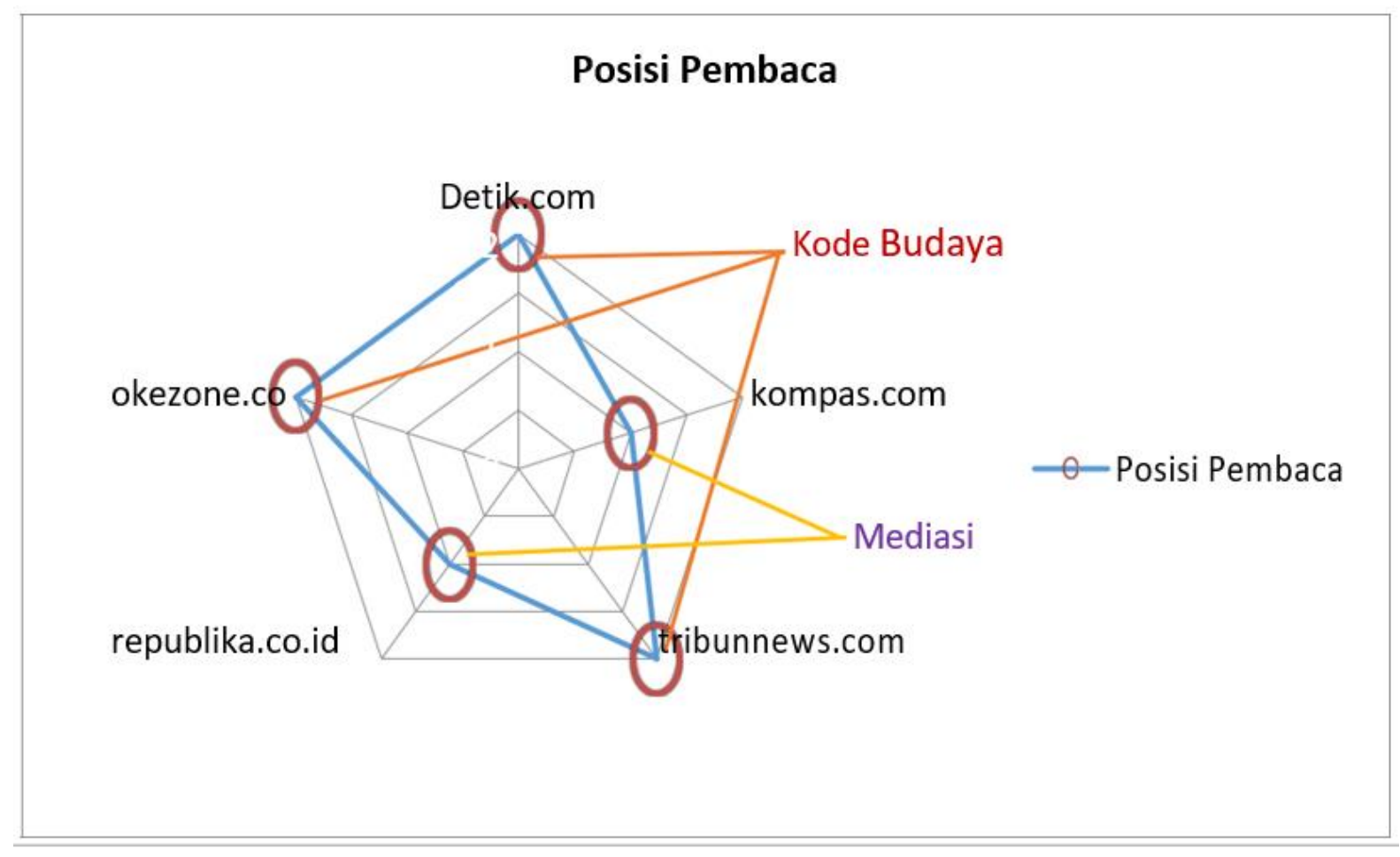

Grafik 2. Posisi Pembaca

3. Posisi Media

Situs berita online detik.com menghadirkan sosok perempuan (Menteri Susi) sebagai sosok yang mampu dan berhasil menjalankan peran-peran publik dan pemerintahan dengan baik. Oleh karena itu, dapat dikatakan bahwa media detik.com memberikan citra positif terhadap Menteri Susi. Kompas.com menggambarkan Menteri Susi sebagi seorang perempuan yang tangguh dalam penegakan hukum dengan menenggelamkan kapal dan menjadi sejarah di dunia perikanan indonesia. Oleh karena itu, dapat dikatakan media kompas.com memberikan citra yang sangat positif terhadap perempuan yang memiliki prestasi seperti menteri susi. Berbeda dengan Tribunnews yang tidak menggambarkan secara langsung maupun tidak langsung tentang sosok menteri Susi, disini penulis hanya melaporkan berita tentang penenggelaman kapal yang dipimpin menteri Susi dengan menjelaskan bahan peledak yang digunakan dan pemberitahuan atau notifikasi kepada negara-negara asal kapal yang ditenggelamkan, dan menggambarkan pemerintah sebagai pihak yang memberantas IUUF. Senada dengan republika.co.id yang juga tidak menggambarkan secara langsung maupun tidak langsung tentang sosok menteri susi, disini penulis hanya melaporkan berita tentang tenggelamnya 81 kapal pencurian ikan ilegal yang dipimpin menteri Susi. Berbeda dengan okezone.com yang menggambarkan Susi sebagi seorang menteri perempuan yang mampu menegakan hukum penenggelaman kapal dan menjadi sejarah di dunia perikanan Indonesia. Oleh karena itu, dapat dikatakan media okezone.com memberikan citra yang sangat positif terhadap perempuan yang memiliki prestasi seperti menteri susi.

Media massa mampu melakukan perubahan paradigma berkaitan dengan pencitraan perempuan yang selama ini dipakai, (Mills, Language and Sexism) yaitu cenderung seksis, objek iklan, objek pelecehan, dan ratu dalam ruang publik perlu diperluas wacanaanya menjadi subjek dan mampu menjalankan peran-peran publik dalam ruang publik. Hal inilah yang dilakukan dalam pemberitaan Penenggelaman Kapal di Perairan Indonesia telah mampu menghadirkan Menteri Perempuan sebagai sosok yang berhasil menjalankan peran-peran publik. Menteri perempuan yang tegas, berani, cerdas dan berdedikasi. 


\section{Simpulan}

Pemberitaan penenggelaman kapal diperairan Indonesia pada kelima situs berita online terpopuler di Indonesia telah berusaha untuk menghadirkan perbedaan yang cukup signifikan baik dalam pemberitaan maupun dalam menampilkan gambar serta judul pada berita. Selain itu, berbedanya posisi subjek (pencerita/penulis) disetiap situs berita online maka berbeda pula penggambaran objeknya (Menteri Susi) Pada dua situs berita online subjeknya adalah seorang perempuan sehingga penggambaran objek yang juga seorang perempuan semakin berkembang dengan adanya isu perempuan. Namun berbeda ketika subjeknya seorang laki-laki ketika menggambarkan gagasan perempuan dengan menampilkan diri perempuan itu sendiri, subjek tidak dapat mengembangkan dengan menampilkan gagasan yang dimiliki penulis. Berbeda dengan dua penulis laki-laki sebelumnya, subjek laki-laki dari salah satu situs berita online juga cukup baik dengan menampilkan gagasan dari diri objek sendiri dan juga ditampilkan oleh subjek. Selanjutnya Penempatan posisi pembaca dalam berita ini juga menjadi salah satu faktor yang membantu terbentuknya konstruksi perempuan yang positif. Sehingga dengan disisipkannya kode budaya maka pembaca akan menyetujui gagasan dari penulis terhadap orientasi nilai yang ada pada masyarakat, sehingga pembaca akan menempatkan dirinya pada tokoh utama dalam teks. Terakhir adapun posisi situs berita online yang memberikan citra positif terhadap perempuan ddalam hal ini Menteri Susi. Adapun situs berita online tersebut yaitu detik.com, kompas.com dan okezone.com. sedangkan yang memberitakan secara netral adalah tribunnews.com dan republika.co.id.

\section{Ucapan Terima Kasih}

Pada bagian ini, tuliskan orang-orang yang membantu anda secara teknis saat penelitian dilakukan, seperti tempat penelitian, penyedia bahan penelitian, pengolahan data, penyandang/pemberi dana, atau orang-orang yang memberikan kritik membangun sebelum naskah diterbitkan. Jelaskan bagaimana orangorang tersebut berkontribusi.

\section{Daftar Rujukan}

Arikan, Seda. "Angela Carter's The Bloody Chamber: A Feminist Stylistic Approach." Firat University Journal of Social Sciences/Sosyal Bilimler Dergisi 26.2 (2016). doi:10.18069/firatsbed.346908.

Darweesh, D., and H. Ghayadh. "Investigating Feminist Tendency In Margaret Atwood's "The Handmaid's Tale" In Terms Of Sara Mills' Model. A Feminist Stylistic Study." British Journal of English Linguistics 4.3 (2016): 21-34.

Van Dijk, Teun A., ed. Discourse as structure and process. Vol. 1. Sage, 1997.

Fairclough, Norman. Critical Discourse Analysis The Critical Study of Langauge. Second Edi, Routledge, 2010.

---. Critical Discourse Analysis The Critical Study of Language. Longman Publishing, 1995.

---. Language and Power. Longman Publishing, 1989.

Fisher, A. "Addicted to Talk: Newspaper representations of the female speaking subject." Working with English: medieval and modern language, literature and drama 7 (2011): 14-32.

Foucault, Michel, et al. Discourse The New Critical Idiom. Routledge, 1997.

Gauntlett, David. Media, Gender and Identity : An Introduction. Routledge, 2005.

Gill, Rosalind. "Postfeminist media culture: Elements of a sensibility." European journal of cultural studies 10.2 (2007): 147-166. doi:10.1177/1367549407075898.

Jorgensen, Marianne, and Louise J. Phillips. Discourse Analysis as Theory and Method. SAGE Publication Ltd, 2002.

Kress, Gunther, and Van Theo Leeuwen. Multimodal Discourse The Modes and Media of Contemporary Communication. Edited by Oxford University Press, 2001.

Liddle, Joanna, and Shirin Rai. "Feminism, Imperialism and Orientalism: the challenge of the 'Indian woman'." Women's History Review 7.4 (1998): 495-520, doi:10.1080/09612029800200185 